\section{Response to: 'On using machine learning algorithms to define clinically meaningful patient subgroups' by Knevel and Huizinga}

We thank Knevel and Huizinga for their good comments ${ }^{1}$ on our work in which we used hierarchical clustering on principal components to define clinically meaningful subgroups of patients with anti-Ku antibodies ${ }^{2}$ and, to a lesser extent, on the work of Mariampillai $e t a l^{3}$ in which the authors used a similar method to reveal subgroups of myositis and propose a classification of these diseases.

Knevel and Huizinga nicely explain how this statistical tool is a useful alternative to detailed insight in pathogenesis to improve taxonomy and personalise medicine. In this regards, myositis, which is rare and heterogeneous condition, is perfectly fitted for this method.

Knevel and Huizinga also challenge the concern about these techniques raised by Pinal-Fernandez and Mammen through a statistical sophistry. ${ }^{4}$ In this regards, the initiative started by the European League Against Rheumatism (EULAR) to guide the use of big data techniques for rheumatic and musculoskeletal diseases will help to promote the development and the standardisation of these tools. ${ }^{5}$

Finally, Knevel and Huizinga point out the importance of the validation of the findings. Given the extreme rarity of anti-Ku patients, we used k-fold cross-validation method as detailed by the authors. ${ }^{12}$ Furthermore, Mariampillai et $a l^{3}$ have used the independent cohort of 50 patients to confirm 4 groups of myositis they highlighted through hierarchical clustering on principal components analysis.

As a conclusion, myositis and related conditions are examples of musculoskeletal diseases that are well fitted for big data techniques such as hierarchical clustering on principal components. We welcome the initiative of EULAR to further improve the development and the standardisation of these techniques. ${ }^{5}$

\footnotetext{
Alain Meyer, ${ }^{1,2}$ Lionel Spielmann ${ }^{\circ},{ }^{3}$ François Séverac ${ }^{4,5}$

${ }^{1}$ Exploration Fonctionnelle Musculaire, Service de physiologie, Hôpitaux Universitaires de Strasbourg, Strasbourg, France

${ }^{2}$ Centre National de Référence des Maladies Auto-Immunes Systémiques Rares de I'Est et du Sud-Ouest, Service de rhumatologie, Hôpitaux Universitaires de Strasbourg, Strasbourg, France
}

${ }^{3}$ Service de Rhumatologie, Hôpitaux civils de Colmar, Colmar, France

${ }^{4}$ Service de Santé Publique, GMRC, CHU de Strasbourg, Strasbourg, France

${ }^{5}$ ICube, UMR 7357, équipe IMAGeS, université de Strasbourg, Strasbourg, France

Correspondence to Dr Lionel Spielmann, Service de Rhumatologie, Hospices civils de Colmar, Colmar 68000, France; lionel.spielmann@ch-colmar.fr

\section{Handling editor Josef S Smolen}

Funding The authors have not declared a specific grant for this research from any funding agency in the public, commercial or not-for-profit sectors.

Competing interests None declared.

Patient consent for publication Not required.

Provenance and peer review Commissioned; internally peer reviewed.

(C) Author(s) (or their employer(s)) 2020. No commercial re-use. See rights and permissions. Published by BMJ.

\section{Check for updates}

To cite Meyer A, Spielmann L, Séverac F. Ann Rheum Dis 2020;79:e155.

Received 15 July 2019

Accepted 7 August 2019

Published Online First 17 August 2019

\section{Linked}

http://dx.doi.org/10.1136/annrheumdis-2019-215959

Ann Rheum Dis 2020;79:e155. doi:10.1136/annrheumdis-2019-215989

\section{ORCID iD}

Lionel Spielmann http://orcid.org/0000-0003-1057-6890

\section{REFERENCES}

1 Knevel R, Huizinga TW, Knevel R. On using machine learning algorithms to define clinically meaningful patient subgroups. Ann Rheum Dis 2020;79:e155.

2 Spielmann L, Nespola B, Séverac F, et al. Anti-Ku syndrome with elevated CK and antiKu syndrome with anti-dsDNA are two distinct entities with different outcomes. Ann Rheum Dis 2019;78:1101-6.

3 Mariampillai K, Granger B, Amelin D, et al. Development of a new classification system for idiopathic inflammatory myopathies based on clinical manifestations and myositisspecific autoantibodies. JAMA Neurol 2018;75:1528-37.

4 Meyer A, Spielmann L, Séverac F. On how to not misuse hierarchical clustering on principal components to define clinically meaningful patient subgroups. Response to: 'On using machine learning algorithms to define clinical meaningful patient subgroups' by Pinal-Fernandez and Mammen. Ann Rheum Dis 2020;79:e129.

5 Gossec L, Kedra J, Servy H, et al. EULAR points to consider for the use of big data in rheumatic and musculoskeletal diseases. Ann Rheum Dis 2020:79:69-76. 